\title{
Buildings for Dollars and Oil: East German and Romanian Construction Companies in Cold War Iraq
}

\author{
Łukasz Stanek (it) \\ Manchester Architecture Research Group, School of Environment, Education \& Development, Room 1.12, Humanities \\ Building, The University of Manchester, Oxford Road, M139PL Manchester, UK \\ Lukasz.stanek@manchester.ac.uk
}

\begin{abstract}
This article discusses the partial integration of companies from socialist Eastern Europe into the nascent economic globalisation in the late Cold War. By focusing on the industrial slaughterhouse designed and built in Baghdad by East German and Romanian companies (1974-81), it shows how they operated within and across the political economy of state socialism and the emerging, Western-dominated market of construction services. In Baghdad, East Germans and Romanians struggled with working across differing monetary regimes, inefficient corporate structures and the requirement to comply with Western standards and regulations. This article shows how they strived to bypass obstacles and to exploit opportunities stemming from their liminal and unequal position in Iraq. By zooming into architectural and engineering documentation, it argues that petrobarter agreements, or the exchange of crude oil for goods and services, shaped programmes, layouts, technologies and materialities of buildings constructed by Eastern Europeans in Iraq and the region.
\end{abstract}

In January 1981 representatives of Iraq's Ministry of Agriculture and Agrarian Reform opened Baghdad's new industrial slaughterhouse, an ensemble built in the southern suburbs of the Iraqi capital [Figure 1]. The facility, consisting of eighteen buildings located on thirty-four hectares bordering the Tigris river, was designed, constructed, equipped and put into operation by several East German state enterprises in cooperation with a Romanian contractor in charge of the construction of the buildings, and subcontractors from Iraq, Western Europe and socialist countries [Figure 2]. This project was part of a longer history of Eastern European exchanges with Iraq in the wake of the 1958 coup which toppled the pro-Western monarchy, and it testified to the continuing role of Eastern Europeans in programmes of modernisation of Iraq. Presented in the Iraqi press as the biggest and most modern in Arab countries, the abattoir showcased the advancement of the agrarian reform implemented by the Ba'ath party and Saddam Hussein, Iraq's president since 1979. But the project was also indicative of a new phase in the exchanges between Eastern Europe and Iraq after the 1973 oil embargo. In the wake of the embargo and the boom that followed, Iraq became a major source of convertible currency, badly needed by socialist countries in order to alleviate their debt crisis. These countries equally needed crude oil, exchanged for Eastern European goods and services in a procedure called petrobarter. ${ }^{1}$

By focusing on the Baghdad abattoir as part of accelerated economic exchanges between Eastern Europe and Iraq during the two last decades of the Cold War, this article advances the debate about the role of socialist countries in the processes of economic globalisation. In recent years, Cold War historians have taken issue with the Western-centric understanding of globalisation as the worldwide spread of economic, technological and cultural phenomena from the United States

\footnotetext{
1 On petrobarter, see Douglas Rogers, 'Petrobarter: Oil, Inequality, and the Political Imagination in and after the Cold War', Current Anthropology, 55, 2 (2014), 131-53.

(C) The Author(s), 2021. Published by Cambridge University Press. This is an Open Access article, distributed under the terms of the Creative Commons Attribution licence (http://creativecommons.org/licenses/by/4.0/), which permits unrestricted re-use, distribution, and reproduction in any medium, provided the original work is properly cited.
} 


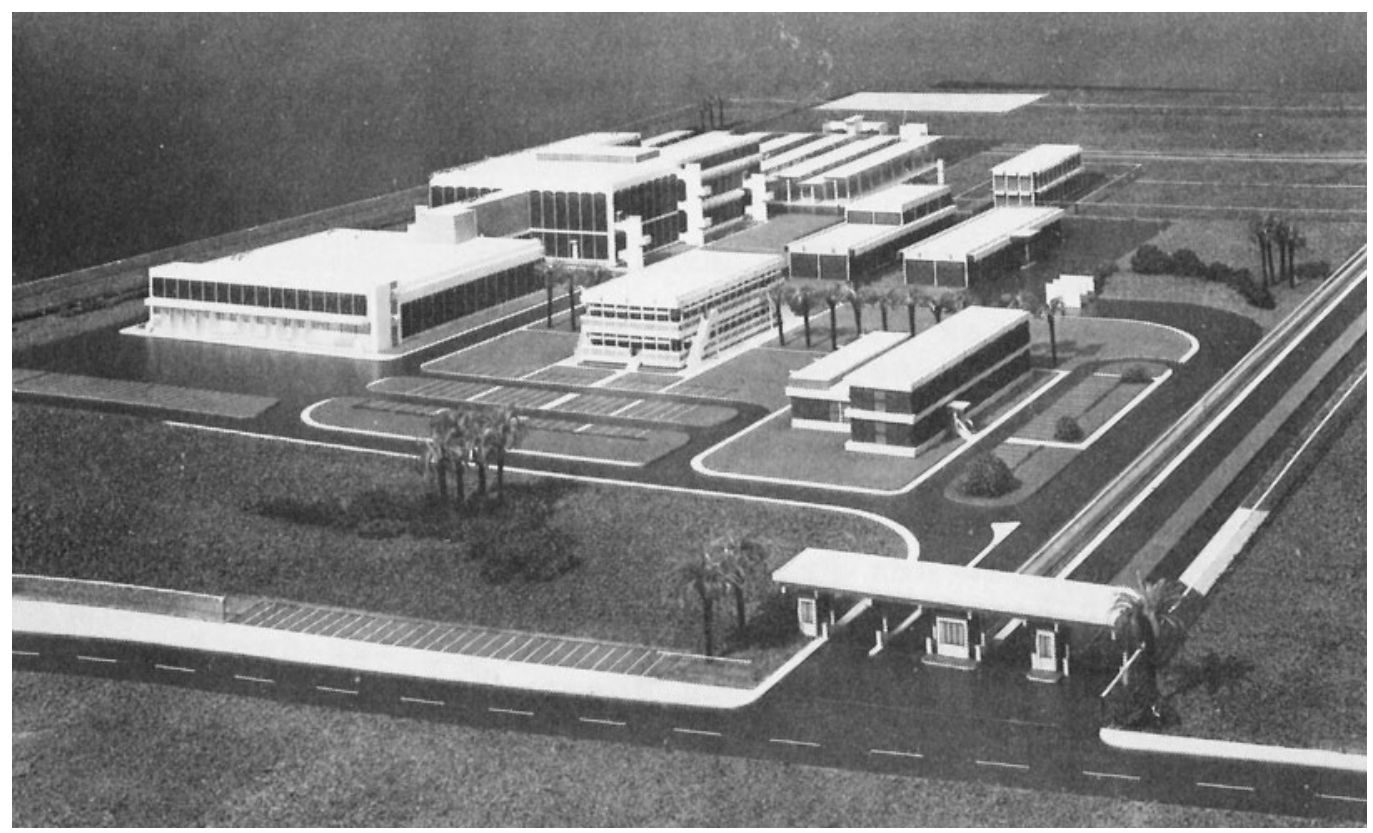

Figure 1. Modern slaughterhouse Baghdad, model. Ipro-Dessau (German Democratic Republic). 'VEB Industrieprojektierung Dessau: Betriebschronik', vol. 2, n.d.

and Western Europe. ${ }^{2}$ Scholars have pointed out that, like the rest of the world, during the 1970s the socialist countries were both affected by and responded to the 'shock of the global', including the oil crisis, rising interest rates on international markets, industrialisation outside the West and the increasing intertwinement of global trade. ${ }^{3}$ These phenomena impacted Eastern Europe's relationship with the Global South within what scholars described as a broader shift from the principle of political solidarity during the Khrushchev period to the prioritising of economic interest during the Brezhnev era, even if, as many pointed out, economy and politics were intertwined in both periods. ${ }^{4}$ Reflecting on these processes, several scholars reconstructed projects of globalisation that Eastern Europeans proposed as an 'alternative' to the Western one. ${ }^{5}$ Others pointed to the entanglement between actors from the East, the West and the South during the two final decades of the Cold War within a globalisation that was at the same time shared and segmented. ${ }^{6}$

2 James Mark, Artemy M. Kalinovsky and Steffi Marung, eds., Alternative Globalizations: Eastern Europe and the Postcolonial World (Bloomington, IN: Indiana University Press, 2020). See also David Engerman, 'The Second World's Third World', Kritika: Explorations in Russian and Eurasian History, 12, 1 (2011), 183-212; James Mark and Quinn Slobodian, 'Eastern Europe', in Martin Thomas and Andrew Thompson, eds., The Oxford Handbook of the Ends of Empire (Oxford: Oxford University Press, 2017); Oscar Sanchez-Sibony, Red Globalization: The Political Economy of the Soviet Cold War from Stalin to Khrushchev (Cambridge: Cambridge University Press, 2014).

3 Niall Ferguson et al., eds., The Shock of the Global: The 1970s in Perspective (Cambridge, MA: Belknap, 2010); Richard H. Immerman and Petra Goedde, eds., The Oxford Handbook of the Cold War (Oxford: Oxford University Press, 2013).

4 Mark and Slobodian, 'Eastern Europe'; Anne Dietrich, 'Zwischen solidarischem Handel und ungleichem Tausch: Zum Südhandel der DDR am Beispiel des Imports kubanischen Zuckers und äthiopischen Kaffees', Journal für Entwicklungspolitik, 30, 3 (2014) 48-67; James Mark and Yakov Feygin, 'The Soviet Union, Eastern Europe, and Alternative Visions of a Global Economy 1950s-1980s', in Mark et al., eds., Alternative Globalizations, 35-58. See also: Artemy Kalinovsky, Laboratory of Socialist Development: Cold War Politics and Decolonization in Soviet Tajikistan (Ithaca, NY: Cornell University Press, 2018); Elidor Mëhilli, From Stalin to Mao: Albania and the Socialist World (Ithaca, NY: Cornell University Press, 2017).

5 Mark et al., eds., Alternative Globalizations.

6 Akira Iriye, ed., Global Interdependence: The World after 1945 (Cambridge, MA: Belknap, 2014). 


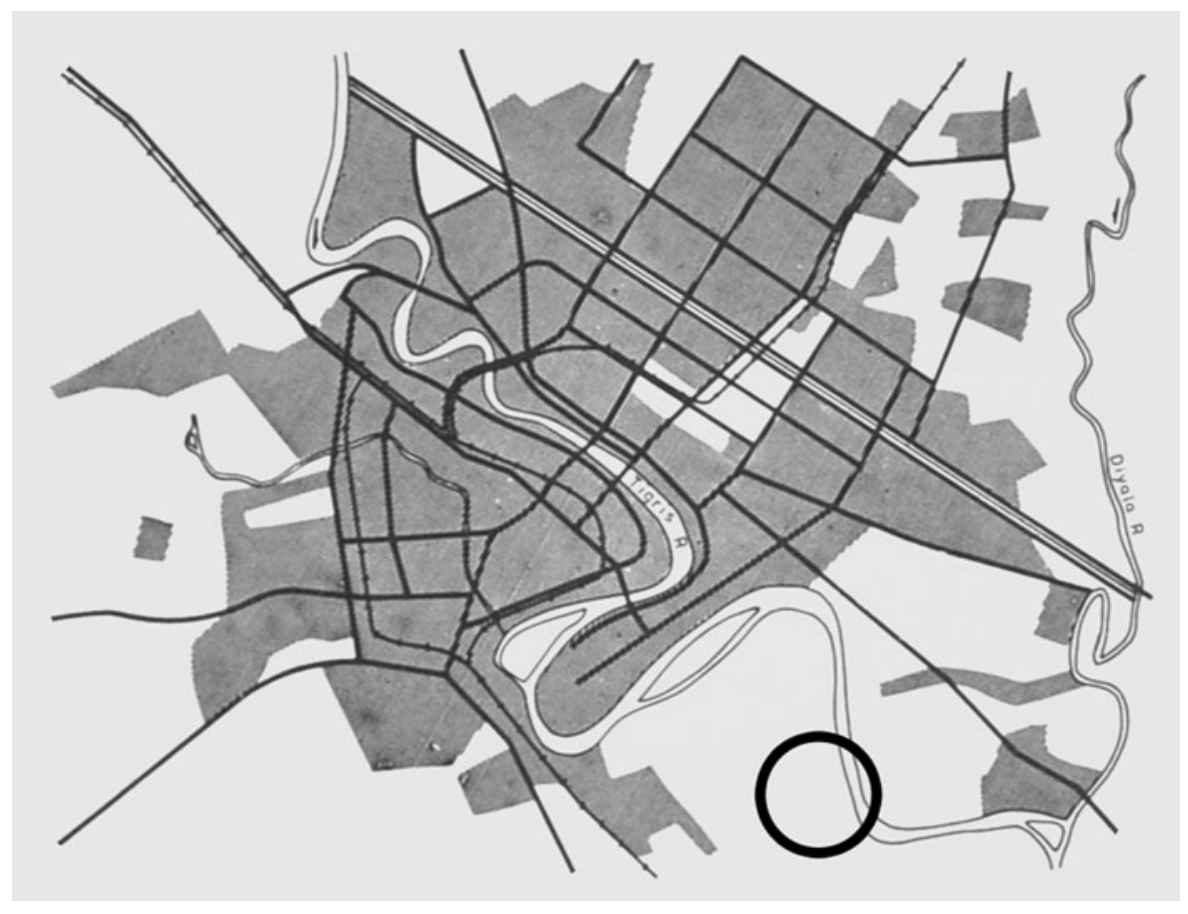

Figure 2. Location of the slaughterhouse in Baghdad. Drawn by the author, on the basis of a schematic map of Baghdad (1975), issued by the Summer Resorts and Tourism Service (Iraq). Library of Congress, Washington DC (USA), G7614.B3 1975.D6.

This article advances the latter position. Eastern European companies and professionals who worked in Iraq and the region during the 1970s and 1980s, including those involved in the construction of the Baghdad abattoir, did not propose to their Iraqi counterparts an international economic system alternative to that practised by the West. The engineers and managers on the construction site in Baghdad were fully aware that they were operating on a market of design and construction services that was dominated by Western companies, products, standards and financial instruments. This was also evident to decision makers and scholars in socialist countries. For example, in 1971 the former president of the Hungarian Economic Association claimed that the 'socialist "world market" revealed itself to be a fiction'. ' Even when Soviet economists during the late Brezhnev period discussed the prospects of the 'world socialist system', consisting of the Council of Mutual Economic Assistance (COMECON) and countries with preferential trade relationships with the COMECON, they conceded that these countries were differing in political and economic systems and were often intertwined with Western economies. ${ }^{8}$

Concurring that by the 1970 s socialist countries were 'an increasingly integral part of the capitalist world economy', 9 scholars demonstrated many facets of this integration. They discussed the membership of several Eastern European countries in the General Agreement on Tariffs and Trade (GATT), as well as their rapprochement with the International Monetary Fund (IMF) and the World Bank, all institutions which spearheaded Western-led globalisation. ${ }^{10}$ Scholars also pointed at the acceptance

\footnotetext{
7 Quoted in A. G. Frank, 'Long Live Transideological Enterprise! The Socialist Economies in the Capitalist International Division of Labor', Review (Fernand Braudel Center), 1, 1 (1977), 120.

8 Leon Zalmanovich Zevin, Economic Cooperation of Socialist and Developing Countries: New Trends (Moscow: Nauka, 1976).

9 Frank, Enterprise, 94.

10 L. Haus, 'The East European Countries and GATT: The Role of Realism, Mercantilism, and Regime Theory in Explaining East-West Trade Negotiations', International Organization, 45, 2 (1991), 163-82; André Steiner, 'The Globalisation
} 
of world market prices as the basis for COMECON trade, joint ventures with Western firms in Eastern Europe, Eastern European industrial exports to the Global South and 'tripartite' collaboration which included contractors from the West, the East and the South. ${ }^{11}$ However, as others observed, this integration was far from smooth, as it was constrained both by Eastern Europe's own internal regulations and by defensive positions of the West. ${ }^{12}$ The close reading of the encounter between East German and Romanian companies, Western controllers and Iraqi decision makers in Baghdad will clarify the character of this partial integration of companies from socialist countries into the globalising market in Iraq and the region.

In what follows, I argue that the position of Eastern European companies in Baghdad was, first, liminal, as they were operating at the intersection between the increasingly global and Western dominated market of design and construction services and the political economy of state socialist foreign trade. The latter was defined by state monopoly, the inconvertibility of Eastern European currencies and the privileging of countertrade, including petrobarter. Second, the position of Eastern European actors in Iraq was unequal to that of their Western competitors. Under pressure to acquire convertible currencies, their work was restricted by the need to operate across differing monetary systems, inefficient corporate structures and the increasingly common requirement to comply with Western standards, norms and regulations. By discussing their work, this article will clarify the terms of a globalisation fuelled by petrodollars and petrobarter and show the liminal and unequal position of East German and Romanian actors within it. The focus on two socialist countries will show their commonalities but also the division of labour between them and differences in their ways of working with Iraqi clients and Western competitors. While minutes of negotiations and reports from the construction site reveal how state socialist managers and decision makers struggled with working across two political economies, the final part of this article will explore how they tried to exploit the differences between these economies. In particular, it will show how the opportunities brought about by the petrobarter procedure were translated into programmes, layouts, technology and materiality of buildings in Iraq and elsewhere in the region. These translations come to the fore in architectural blueprints, engineering drawings and operational flow charts, and by focusing on these technical documents this article will make a case for extending sources of Cold War historiography towards architectural and engineering archives.

\section{East Germany and Romania in Iraq}

Shortly after the 1958 coup and Iraq's withdrawal from the pro-Western Baghdad Pact, the government of Abd al-Karim Qasim signed treaties of technical cooperation and assistance with the Soviet Union, followed by Poland, Bulgaria, Hungary and Czechoslovakia. ${ }^{13}$ While Iraq kept its distance from the COMECON in terms of internal, economic and foreign policies, the Soviets and Eastern Europeans continued to be involved with the subsequent Iraqi governments, including the short-lived Ba'ath government (1963), the Arif regime (1963-8) and the second Ba'ath rule (since 1968). In spite of tensions around the prosecution of Iraqi communists and disagreements about the Kurdish question, the socialist countries provided long-term credit, training, personnel and

Process and the Eastern Bloc Countries in the 1970s and 1980s', European Review of History/ Revue européenne d'histoire, 21, 2 (2014), 165-81.

11 Laszlo Csaba, Eastern Europe in the World Economy (Cambridge: Cambridge University Press, 1990); Friedrich Levcik and Jan Stankovsky, Industrial Cooperation between East and West (London: Routledge, 2017); Besnik Pula, Globalization Under and After Socialism: The Evolution of Transnational Capital in Central and Eastern Europe (Stanford: Stanford University Press, 2018); Patrick Gutmann, 'The East and Tripartite Industrial Cooperation in the Cold War Era: A Retrospective Analysis', Eastern European Economics, 49, 2 (2011), 82-99.

12 Steiner, 'Globalisation'.

13 Oles M. Smolansky, The USSR and Iraq: The Soviet Quest for Influence (Durham, NC: Duke University Press, 1991); 'Czechoslovakia Will Set Up Ceramic Industry', Iraq Times (IT), 27 Feb. 1961, 3; 'Hungarian Flour Mills for Iraq', IT, 2 Mar. 1961, 1; 'Talks on Study Contracts for 4 Czech Projects Soon', IT, 23 July 1961, 3; 'Engineering Fabrication Plant to Be Built in Dora', IT, 25 Jan. 1962, 2. 
know-how for the realisation of the Ba'athist programme of a planned economy with state ownership of national resources and state control over most of the economy, industrialisation and broad distribution of welfare. ${ }^{14}$

The 1972 fifteen-year Treaty of Friendship and Cooperation between Iraq and the Soviet Union was the high point of these exchanges, which were instrumental for the nationalisation of the Iraq Petroleum Company (1972) and the development of the Iraqi oil industry. The transformation of agriculture, with large hydroengineering projects such as dams and land reclamation, as well as industrialisation, were the principal areas of this exchange, together with military cooperation. Besides industrial and infrastructural investments, among the most visible results of Iraq's collaboration with socialist countries in architecture and planning was the construction of Baghdad's international airport by Bulgarian firms in the 1960s, as well as master plans of Baghdad $(1967,1973)$ and the country's General Housing Programme (1976-80), delivered by Polish planners. Eastern Europeans often staffed administrative offices in Iraq, planning institutions, private architectural firms and the newly established (1959) School of Architecture at the University of Baghdad. By the 1970s the rapprochement with Yugoslavia led to several high-profile buildings being constructed in Baghdad by Yugoslav companies in anticipation of the Non-Aligned Congress in 1982 (relocated to New Delhi). ${ }^{15}$

These exchanges were based on the demand for architectural and construction projects in the country, combined with the saturation, then stagnation, of most Eastern European markets. The complementary political and economic interests by socialist countries and Iraq and the relative geographic proximity of both regions further facilitated this export. It expanded in the wake of the 1973 oil embargo as part of the accelerated circulation of Middle Eastern and North African oil, Western money and Eastern European goods and services. The profits from oil sales, deposited by Arab governments with Western financial institutions, were lent to socialist countries in need of modernising their industries and financing their models of consumer societies. Yet when their industrial leap failed to materialise, socialist countries, among them East Germany and Romania, found themselves struggling with huge debts in foreign currencies. ${ }^{16}$ With rising interest rates in international capital markets, this debt became increasingly difficult to finance due to the diminishing competitiveness of Eastern European industrial production and the increasing cost of fossil fuels, including oil and gas delivered from the Soviet Union. In this context Iraq emerged as the main recipient of Eastern European trade among oil producing countries and a major source of convertible currencies and crude oil for socialist Europe. ${ }^{17}$ Once obtained, crude oil was either used to satisfy the rapidly increasing demand by the energy hungry economies in socialist countries or sold to the West to provide supplementary income for debt repayment.

While the design and construction of the Baghdad slaughterhouse was part of these longer exchanges with Eastern Europe, the East German and Romanian actors in charge of this project were relative newcomers to Iraq. Both East Germany and Romania had initiated contacts with Iraq a few months after Qasim's coup, but these exchanges took off less vigorously than those with other countries in the bloc. Under the threat of West Germany's Hallstein Doctrine, Iraq was reluctant to recognise East Germany in order not to risk West German diplomatic and economic sanctions. Full diplomatic relations were established only when Iraq broke off contacts with West Germany after its recognition of Israel (1965). ${ }^{18}$ Trade played an increasingly important role in these contacts, in particular since the 1970s, when East Germany became recognised internationally. ${ }^{19}$ While Romania

\footnotetext{
14 Smolansky, USSR; Massimiliano Trentin, “'Tough Negotiations”: The Two Germanys in Syria and Iraq, 1963-74', Cold War History, 8, 3 (2008), 353-80.

15 Łukasz Stanek, Architecture in Global Socialism: Eastern Europe, West Africa, and the Middle East in the Cold War (Princeton, NJ: Princeton University Press, 2020), 168-237.

16 Stephen Kotkin, 'The Kiss of Debt: The East Bloc Goes Borrowing', in Ferguson et al., eds., Shock, 80-93.

17 Jan Vaňous, 'Soviet and East European Trade and Financial Relations with the Middle East', Soviet and Eastern European Foreign Trade, 21, 1-3 (1985), 86-119.

18 Trentin, 'Negotiations'.

19 Michel Vale and Hanns-Dieter Jacobsen, 'Strategy and Focal Points of GDR Foreign Trade', International Journal of Politics, 12, 1-2 (1982), 125-50.
} 
had established diplomatic relations with Iraq already in 1958, its refusal to sever contacts with Israel was an impediment to the intensification of economic relationships with Arab countries until the mid-1970s.

Romanian and East German economic exchanges with Iraq reflected the fact that these two countries stood at opposite ends of the economic spectrum in socialist Europe. While East Germany's aspirations to an economic world class (Weltniveau) were only warranted for very few branches of its industry, it belonged to the most advanced industrial countries of Eastern Europe. This technological expertise was promoted by East Germany in developing countries, often by means of generous technical assistance. ${ }^{20}$ In Iraq, German engineering expertise had been known since the construction of the Baghdad railway under the Ottoman Empire, followed by German designs of railway infrastructure and public buildings. However, representatives of East Berlin rarely referred to these precedents in order to avoid an association with German imperialism.

In contrast, Romania sought to forge its relationship with African and Asian countries by proclaiming itself a 'socialist developing country'. ${ }^{21}$ Nicolae Ceaușescu (in power between 1965 and 1989) imagined himself to be a leader of the developing world and recruited Romanian construction and design firms in this diplomatic offensive. ${ }^{22}$ In distinction to the close allegiance of East German leadership to the Soviet Union, Ceaușescu's suspicion of Soviet hegemony resonated with many Arab countries that were also wary of Soviet influence. ${ }^{23}$ Along these lines, Romania became a strong supporter of the New International Economic Order (NIEO), with its insistence on non-interference, mutual advantage and sovereign control of each country's resources. ${ }^{24}$

Following the practice of coordinating foreign trade among COMECON countries, East Germany and Romania established joint intergovernmental commissions with Iraq. These commissions identified potential areas of bilateral trade and issued trade protocols, according to which Iraqi enterprises and government agencies signed agreements with East German and Romanian Foreign Trade Organisations (FTOs), or state institutions that were mediating all contracts between enterprises from socialist countries and their foreign partners. Some among these contracts were paid in convertible currencies, which since the mid-1970s was the preferred payment form for East Germany, while others were petrobarter agreements, often used by Romania. According to the latter, Iraqi crude oil was exchanged for Romanian goods and services, denominated in US dollars or in Iraqi dinars (pegged to the US dollar), and cleared on a periodic basis.

With crude oil as Iraq's dominant export product, the main task of the joint commissions was to identify goods and services that Iraq could import from East Germany and Romania. Complete industrial plants featured prominently in the export offers of both countries, in particular related to construction materials and oil industries. East Germans extended their offer to design and construction services, from housing through transport (railways) to infrastructure (telecommunication and electricity networks) and agriculture (irrigation projects). As a result, by the 1970s East Germany was Iraq's second biggest economic partner among socialist countries, after the Soviet Union and before Czechoslovakia. ${ }^{25}$ The war with Iran opened new possibilities for military related exports from East

20 Hermann Wentker, 'Für Frieden und Völkerfreundschaft? Die DDR als internationaler Akteur', in Thomas Großbölting, ed., Friedensstaat, Leseland, Sportnation? DDR-Legenden auf dem Prüfstand (Berlin: Links 2009), 155-76. See also Ludger Wimmelbücker, 'Architecture and City Planning Projects of the German Democratic Republic in Zanzibar', The Journal of Architecture, 17, 3 (2012), 407-32; Andreas Butter, 'Showcase and Window to the World: East German Architecture Abroad 1949-1990', Planning Perspectives, 33, 2 (2018), 249-69.

21 Colin W. Lawson, 'National Independence and Reciprocal Advantages: The Political Economy of Romanian-South Relations', Soviet Studies, 35, 3 (1983), 362-75.

22 Dana Vais, 'Exporting Hard Modernity: Construction Projects from Ceaușescu's Romania in the "Third World”, The Journal of Architecture, 17, 3 (2012), 433-51.

23 Arhivele Naționale, Bucharest (AN), f. C. C. al P.C.R., s. Relații Externe, p. 14/1972, n. 672.

24 Lawson, 'National Independence'.

25 'Studie über den Baumarkt des Irak', 1982, Bundesarchiv, Berlin (BA), DH 2/23018; Barbara Liberska, Polska - Irak: gospodarka, stosunki ekonomiczne (Warsaw: PWE, 1982), 135. 
Germany, which the country took advantage of, despite its declared neutrality. ${ }^{26}$ In turn, Romanian exports to Iraq included cement plants, land reclamation and irrigation projects, electricity networks, roads, housing projects throughout the country and industrial facilities, among them the Baghdad slaughterhouse [Figure 3]. ${ }^{27}$

\section{Liminal Positionality}

Observers in the 1970s pointed out that the easing of tensions between socialist and capitalist countries was followed by an increasing entanglement of their economies. ${ }^{28}$ This entanglement took place also in the Global South, including Iraq. A case in point was the international tender to which the abattoir project in Baghdad was put out in April 1974. The tender documentation was prepared by the West German engineering firm Fritz Thier on behalf of the Ministry of Agriculture and Agrarian Reform in Baghdad. ${ }^{29}$ The decision of the East German authorities to participate in the tender stemmed from their ambition to expand the export of industrial plants. The government in East Berlin also intended to intensify economic and technical ties with Iraq, in anticipation of the first session of the East German-Iraqi joint economic commission and the visit to East Berlin of Saddam Hussein, then deputy chairman of the Ba'ath party and deputy head of Iraq's Revolutionary Command Council. In response to the tender, the FTO Transportmaschinen sent an offer on behalf of the company Ascobloc, a producer of food and meat-processing machinery.

The East German offer was the second most expensive in comparison to four others sent to Baghdad, including one from West Germany. Yet, after the intervention of the Iraqi government, this offer was modified and the requested price was reduced. This modified bid was accepted in September 1975 and the contract was signed after it was given a green light by the chairman of East Germany's Council of Ministers, Horst Sindermann. ${ }^{30}$ Soon afterwards Transportmaschinen appointed Romania's Arcom as the subcontractor for construction, since the Iraqi contractor with whom the FTO had entered the bid withdrew in the course of the negotiations. The contract signed between the FTO Transportmaschinen and the Iraqi government in November 1975 was highly unfavourable for the East German side, as the initial price was reduced by 57 per cent in the amended offer. $^{31}$

In retrospect, controllers in East Berlin pointed at the political motivations of East Germany to enter and pursue the project, in spite of its bleak economic prospects. And yet the conventional wisdom that socialist leaderships accepted economic losses because of anticipated political gains does not quite capture the motivation of the decision makers in East Germany. Political and economic motivations were interrelated, and economic calculations in themselves were complex. After pointing at the likely losses of the companies involved in the abattoir project (betrieblicher Nutzen), East German controllers discussed its prospective 'benefits for the national economy' (volkswirtschaftlicher Nutzen). They included the facilitation of further economic cooperation with Iraq, the valuable experience in delivery of abattoirs, the inclusion of East Germany into the international market of turnkey abattoirs and the availability of convertible currency in East Germany's bank accounts. ${ }^{32}$

This latter point was constantly on the minds of the Romanian and East German partners in the slaughterhouse project, who worked under the obligation to acquire convertible currencies (plan de valută in Romanian, Valutaplan in German). In their work in Iraq they were operating across two

\footnotetext{
26 Harald Möller, DDR und Dritte Welt: Die Beziehungen der DDR mit Entwicklungsländern, ein neues theoretisches Konzept, dargestellt anhand der Beispiele China und Äthiopien sowie Irak/Iran (Berlin: Köster, 2004); 'Studie'.

27 Nicolae Spătaru, 'Realizări ale antreprizei romăne de construcții montaj’, Arhitectura (Bucharest), 5 (1980), 18-21; AN, f. C. C. al P.C.R., s. Relații Externe, p. 44/1976, p. 108/ 1977, p. 3/ 1981; and f. C. C. al P.C.R., s. Economică 1979-89, 187, 192, 225.

28 Frank, Enterprise.

29 'Information über die Kontrolle ...', 18 Oct. 1976, BA, DC/10/895.

30 'NSW-Export Schlachthof-Bagdad', 1 Mar. 1976, BA, DC/10/895.

31 'Information ...', 12 Dec. 1978, BA, DH2/22835-2

32 'NSW-Export Schlachthof-Bagdad'.
} 


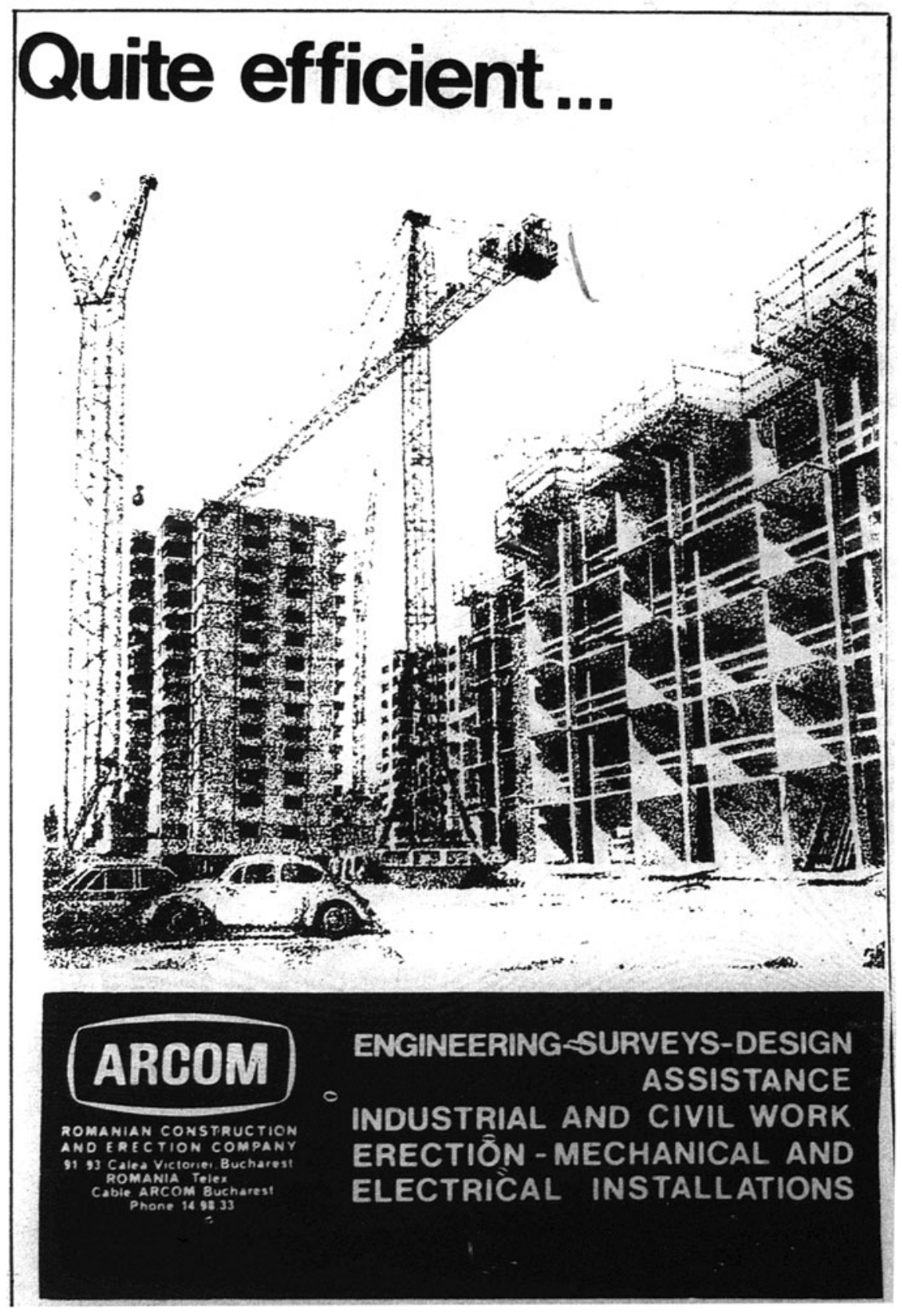

Figure 3. Advertisement of the Romanian contractor Arcom, in charge of the construction of the Baghdad slaughterhouse. Published in the daily newspaper Baghdad Observer (Iraq), September 17, 1976, 2.

monetary systems: that of Eastern European currencies which were inconvertible on international financial markets, and that of exchangeable currencies, including the US dollar, the West German mark and the Iraqi dinar. Yet already the unfavourable contract with the Iraqi side undermined the prospect of profit in convertible currencies for East German companies. This prospect was further diminished by expenses in dollars or dinars, including taxes, shipping costs and insurance fees which were not correctly estimated by East German companies. Nor were costs of equipment and 
materials bought from the West taken into account. As Thier continued to represent the Iraqi commissioners after the tender, it specified Western standards, norms and parameters of performance and construction. The Munich-based engineers often rejected products provided by East German subcontractors and required Western substitutes, paid in convertible currencies. ${ }^{33}$

Further challenges to the project stemmed from East German foreign trade regulations. The obligatory organisational framework for construction export included, first, the FTO, second, the FTO's contractual partner called 'general supplier' who, third, appointed the 'general contractor'. ${ }^{34}$ After several months of negotiations and reviews, the East Berlin-based state enterprise Rationalisierung und Projektierung Berlin (RaPro) was appointed as the general supplier on the Baghdad abattoir project. RaPro was chosen because of its experience as the general supplier of an abattoir in the East German town of Eberswalde, then recently delivered by a West German contractor. ${ }^{35}$ That experience was deemed useful considering the role of Thier in the Baghdad project. The crucial function of the general contractor for construction was given to the firm Industrieprojektierung (Ipro) Dessau. Ipro had specialised in the design of industrial facilities for the production of construction materials and it acted as general contractor for East German construction companies since 1972. The Baghdad abattoir was its first foreign project in this capacity, and Ipro's tasks included the delivery of the architectural design and the supervision of the construction work, as well as the supply of those building materials that were not to be delivered by the Iraqi side. ${ }^{36}$ The remit of Romania's Arcom was defined as the subcontractor for construction. Thirteen other contractors were hired from East Germany, and were complemented by a Yugoslav supplier of insulation and elevators and a West German supplier of waste-water systems. ${ }^{37}$

The ability to bring together a large number of specialised actors in the construction process was presented by socialist countries as a major advantage of centrally planned economies, which they were willing to share with countries on the path of state-led modernisation, such as Iraq. ${ }^{38}$ However, reports from Baghdad challenged this narrative, and Iraqi authorities blamed East German management for the delays on the project. They questioned the division of the responsibilities between East Berlin and the construction site in Baghdad and demanded the relocation of East German decision makers from East Berlin to Iraq. ${ }^{39}$ In order to put pressure on the East German side, they withheld payments, which led to more delays. The deliveries of construction materials by the Iraqi authorities, such as concrete and steel, were also late. Furthermore, the war with Iran interrupted the supply chains and caused construction to stop altogether in autumn $1980 .{ }^{40}$ The prolonged decision-making processes by the East German management, only gradually and partially transferred from East Berlin to the construction site, made it difficult for East German actors to quickly respond to the dynamic situation on the ground. ${ }^{41}$

Further challenges resulted from the collaboration with Arcom. Conflicts between the East German and Romanian companies were particularly embarrassing given the 'political and economic significance' of their collaboration, as representatives of East German ministries pointed out to their Romanian counterparts. ${ }^{42}$ Collaboration between enterprises from various socialist countries was encouraged by COMECON's institutions, and the organisation's Complex Program of Socialist Integration (1971) saw the 'international division of labour' as a means for state socialist companies

\footnotetext{
33 'Abrechung', 12 Dec. 1983, BA, DH2/22835-1.

34 'Stellungnahme', 6 Dec. 1976, BA, DG7-818 3 von 3; Fritz Enderlein, Handbuch der Außenhandelsverträge. 2, Anlagenvertrag, Montagevertrag, Lohnveredlungsvertrag [u. a.] (Berlin: Staatsverl. d. DDR, 1980), 72.

35 Joachim Nawrocki, 'Kombinat für die Genossen', Die Zeit, 13 (1975), available at https://www.zeit.de/1975/13/kombinatfuer-die-genossen (last visited 1 Mar. 2020).

36 'VEB Industrieprojektierung Dessau: Betriebschronik', vol. 2, n.d.; 35 Jahre Dessau im In- und Ausland (Dessau: Bauingenieurkombinat für Anlagenexport, 1985).

37 'Baghdad Modern Slaughterhouse - Gesamtablaufplan', BA, DG7-748.

38 Zevin, Economic Cooperation, 59.

39 'Information', 6 July 1978, BA, DC/8/1731; 'Information', 3 Aug. 1978, BA, DC/10/895.

40 'Abrechung'.

41 'Sonderinformation', 12 Jun. 1979, BA, DG7-745 1 von 2.

42 'Bericht über die Dienstreise nach Bukarest, SRR, von 11.-12.7.1977', BA, DH2/22835-3.
} 
to gain competitiveness on foreign markets. When construction and construction materials industries were concerned, such collaboration was further encouraged by the Permanent Commission of Construction, created in 1958 in East Berlin. Yet while the commission was coordinating some of COMECON's technical assistance to the organisation's least developed countries, in particular Mongolia, commercial projects such as the Baghdad abattoir were not coordinated within the commission. ${ }^{43}$ Rather, East German and Romanian firms found themselves competing against each other in the original tender for the abattoir, when Transportmaschinen in cooperation with an Iraqi contractor was bidding against Romania's Arcom partnered with a West German firm. It was only after the tender was awarded and the withdrawal of the Iraqi partner that Transportmaschinen invited Arcom to join as a subcontractor. ${ }^{44}$

The resulting collaboration was far from smooth. The East German side considered much of the Romanian produced design documentation to be of poor quality and required multiple amendments. These were particularly onerous because of the complex process of acceptance for the drawings: Arcom's drawings were sent from Bucharest to East Berlin to be checked, then to Munich to be approved by Thier, then back to Bucharest to include the required modifications, then back to East Berlin and, finally, to the construction site in Baghdad. ${ }^{45}$ East German decision makers repeatedly requested that Arcom double the size of its construction team in Baghdad in order to catch up with the work, a request that Arcom resisted. ${ }^{46}$

Because of constant disagreements with Arcom, East German managers repeatedly considered replacing the Romanian contractor. No East German company was ready to take over, however. In contrast to East German experience of the construction of cement plants in Syria, where a Bulgarian contractor was replaced by Lebanese companies, the estimation of costs and benefits confirmed that keeping Arcom on board was the least bad scenario. ${ }^{47}$ Furthermore, the East German leadership was concerned that the Iraqis would replace Ipro with a West German contractor. While disagreements with Arcom could rarely be solved on the construction site in Baghdad, the double chains of command of the party and the state, with East German and Romanian companies responding to the ministries in East Berlin and Bucharest, respectively, opened communication channels and possibilities of leverage. In this way, the companies involved were able to muddle through, even if concessions from Arcom required additional payments by East Germany, and financial disagreements were not resolved until the mid-1980s [Figure 4].

The documents that circulated between the construction site in Baghdad and various offices in Bucharest, Berlin and Munich show these places as intersections between state socialism and the emerging, increasingly global market of design and construction services. The work of the East German and Romanian enterprises involved was defined by an intertwinement between politics and economy in both countries and the state monopoly on foreign trade, reflected in rigid export regulations. Critical obstacles for state socialist companies stemmed from their operations within and across two monetary systems, in particular since these companies were increasingly forced to accept Western industrial standards and purchase Western materials and equipment. Corporate structures of state socialist companies and their long decision making processes resulted in delays and missed deadlines. The fact that many East German subcontractors often specialised in a particular technology diminished their flexibility when rising import tariffs on steel, for example, undermined the economic rationale of steel-based projects. ${ }^{48}$

\footnotetext{
43 Kraft, Zusammenarbeit.

44 AN, f. C. C. al P.C.R., s. Relații Externe, p. 60/1975; 'NSW-Export Schlachthof Bagdad'.

45 'Information über den Stand ...', 25 Jan. 1978, BA, DC/10/895.

46 'Bericht', 1 Feb. 1979, BA, DH2/22835-3.

47 'Bericht über Probleme ...', 11 Apr. 1978, BA, DC/10/895; Max Trecker, “'Grapes of Cooperation”? Bulgarian and East German Plans to Build a Syrian Cement Industry from Scratch', in Anna Calori et al. eds., Between East and South: Spaces of Interaction in the Globalizing Economy of the Cold War (Munich: De Gruyter 2019), 33-58.

48 Dieter Warnke, 'Bericht über die durchgeführte Dienstreise in der Zeit vom 18.11.1987-09.12.1987 nach Kuwait und in die V.A.E.'; 'Einschätzung der bisherigen Bautätigkeit in Kuwait und Schlussfolgerungen für die weitere Arbeit'; 'Information zur materiell-technischen Basis des Bauwesens der DDR im Staat Kuwait', BA, DH1/ 32777.
} 


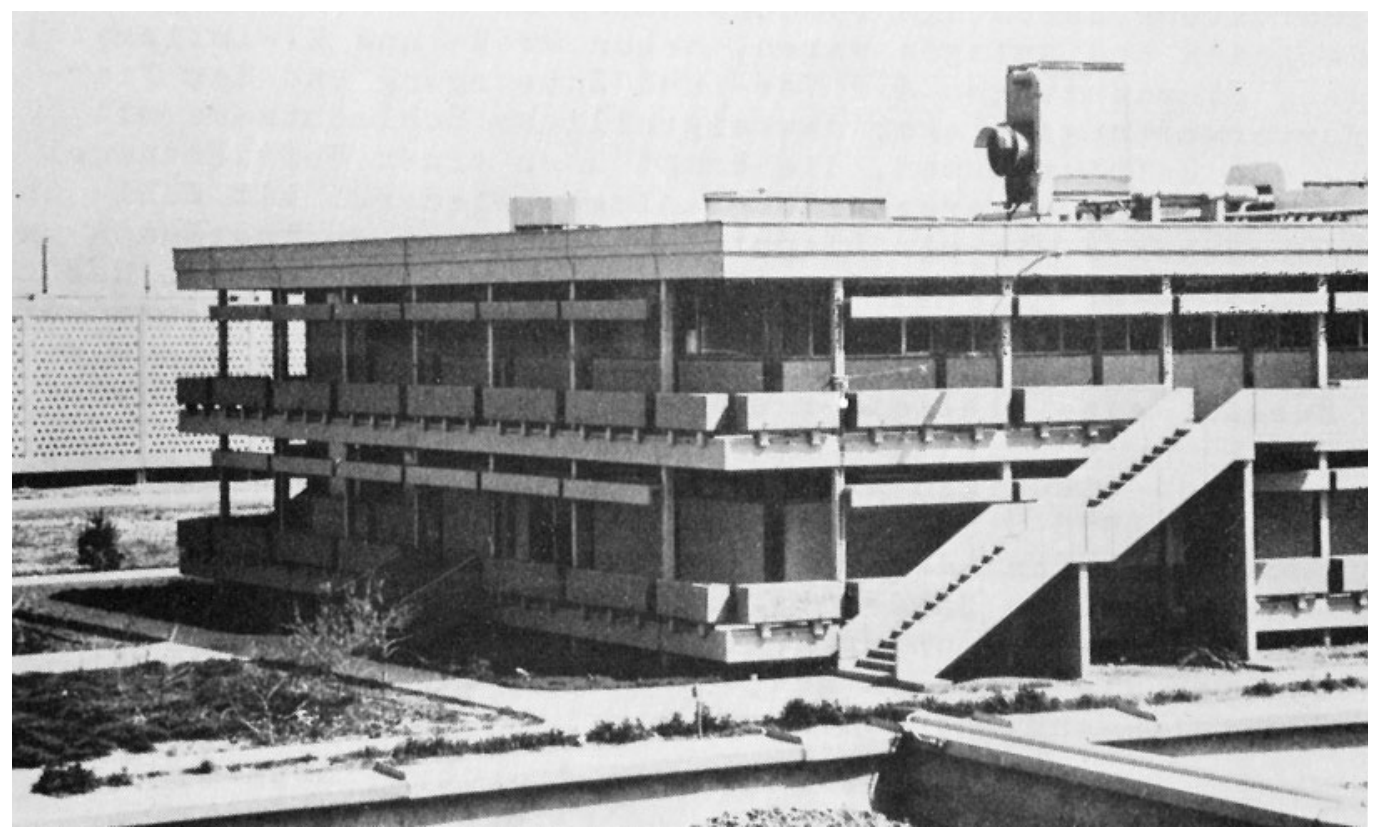

Figure 4. The canteen building after completion at the Baghdad slaughterhouse compound. Ipro-Dessau (German Democratic Republic). 'VEB Industrieprojektierung Dessau: Betriebschronik', vol. 2, n.d.

In the years that followed the construction of the Baghdad abattoir, East German reviewers tried to learn from this disappointing experience. By the 1980s reports sent from the Middle East and North Africa to East Berlin pointed out that East German design institutes and contractors needed to improve their performance along the lines of 'flexibility, variability and risk-taking. ${ }^{49}$ Yet the addressees were rarely able to follow such recommendations, as little had changed in the political economy of East German export. In Iraq, further constraints stemmed from the depletion of the country's monetary reserves during the war with Iran, and the fact that payments in crude oil were often deferred for several years. ${ }^{50}$ In addition, East German companies often found more lucrative commissions in West Germany, which subsidised its eastern neighbour in exchange for political concessions. By the end of the Cold War, East German contractors and design institutes had largely withdrawn from Iraq.

\section{Buildings for Oil}

In contrast to East Germany, during the 1980s Romanian contractors expanded their operations in oil producing countries in the Middle East and North Africa. Romanians targeted these countries after Romania's prospect of insolvency (1980), Ceaușescu's decision to fast-track debt repayment and the hardening of the regime which restricted economic exchanges with Western Europe. ${ }^{51}$ In what follows, I will show how Romanian contractors in Iraq and other oil producing countries responded to the increased pressure to acquire convertible currencies. Rather than attempting to implement in Iraq organisational procedures from back home, they adapted their operations to the conditions on the ground in a way that capitalised on the principle of petrobarter. While historians pointed at the relevance of barter in the foreign trade of socialist countries, ${ }^{52}$ the following zoom into architectural and

\footnotetext{
49 Warnke, 'Bericht', Annex 1, 3; 'Sonderinformation'; 'Kurzbericht'.

50 Möller, DDR und Dritte Welt, 247-8.

51 Kotkin, 'Kiss of Debt', 89.

52 Dietrich, 'Zwischen solidarischem Handel'.
} 
engineering archives will shift the focus from negotiations between politicians and economists to professional practices of architects, engineers and construction managers. ${ }^{53}$ They were in charge of translating the principles of petrobarter into decisions concerning programme, layout, technology and materiality of the buildings delivered. The close reading of their decisions will confirm the pressures under which these professionals worked, but it will also show how they aimed at exploiting their liminal position in Iraq, while sometimes accepting high economic and personal costs.

The imperative to maximise the income in convertible currencies and to minimise their expenditure had been shared since the 1950s by Eastern European socialist countries and by most of the newly independent countries in the Global South. In response, both privileged barter. Barter agreements were not specific to socialist countries, but they were a standard commercial practice among COMECON member states. By the 1960s barter had become the dominant mode of transaction between COMECON countries and their trade partners in Africa and Asia, including Iraq. Petrobarter with Iraq allowed Eastern European countries to avoid the use of convertible currency and to obtain a strategic resource, as well as offering them an outlet for goods of limited marketability, including machinery, equipment and arms. In turn, Iraqis could acquire equipment which the Western countries were not willing to sell them at that time, while paying with oil that they feared would be difficult to sell to the West due to international tensions around the nationalisation of the Iraqi oil industry (1972). Long-term contracts, which often accompanied barter agreements, shielded the participants of the transactions from the fluctuation of prices on the world market. For example, by the second half of the 1970s the Soviet Union continued to exchange their military equipment for Iraqi oil based on prices from before their spike (1973). Consequently, when the Soviets started to re-sell this oil to the West, and to profit from the increased prices, relations with Iraq became strained. ${ }^{54}$

Besides the Soviet Union, Bulgaria, Czechoslovakia, East Germany, Poland and Hungary were also selling imported oil to Western Europe ${ }^{55}$ By contrast, Romania, along with Yugoslavia, used all imported oil for domestic consumption. ${ }^{56}$ In spite of being an oil producer, by the late $1970 \mathrm{~s}$ Romania had become a net importer of crude oil, due to industrialisation and development of huge refinement capacities. With the steep rise of world prices of oil these imports were not offset by the export of oil products and contributed to Romania's foreign exchange crisis (1981-2). ${ }^{57}$

With the privileging of debt repayment the Romanian preference for barter only intensified. Minutes of meetings held by the Romanian leadership with officials responsible for construction export and with Iraqi envoys show that Ceaușescu personally insisted on the expansion of barter transactions. When discussing a report about the delivery of Romanian cement plants to Iraq and several projects for Libya in July 1981, Ceaușescu emphasised the need to use Romanian materials in projects abroad: 'we get involved in these contracts to export [building] materials, designs and intelligence ... because this is where money is made. I'm not going abroad to pour concrete! ${ }^{58}$ During another meeting (1982), he reiterated that commissions abroad should be accepted only when all materials, machinery and labour were delivered from Romania: 'we shouldn't be buying a needle from abroad'. ${ }^{59}$

\footnotetext{
53 For the work on professionals across Cold War divisions, see Sandrine Kott, 'Cold War Internationalism', in Glenda Sluga and Patricia Clavine, eds., Internationalisms: A Twentieth-Century History (Cambridge: Cambridge University Press, 2016), 340-62; Iris Borowy, 'Medical Aid, Repression, and International Relations: The East German Hospital at Metema', Journal of the History of Medicine and Allied Sciences, 71, 1 (2017), 64-92.

54 Smolansky, USSR.

55 Vaňous, 'Soviet and East European Trade'.

56 Ibid.

57 Bogdan Murgescu, 'Anything but Simple: The Case of the Romanian Oil Industry', in Helga Schultz and Eduard Kubů, eds., History and Culture of Economic Nationalism in East Central Europe (Berlin: BWV, 2006), 247-8.

58 AN, f. C. C. al P.C.R., s. Economică 1979-89, 60/ 1303.

59 AN, f. C. C. al P.C.R., s. Cancelarie 1980-89, 28.
} 


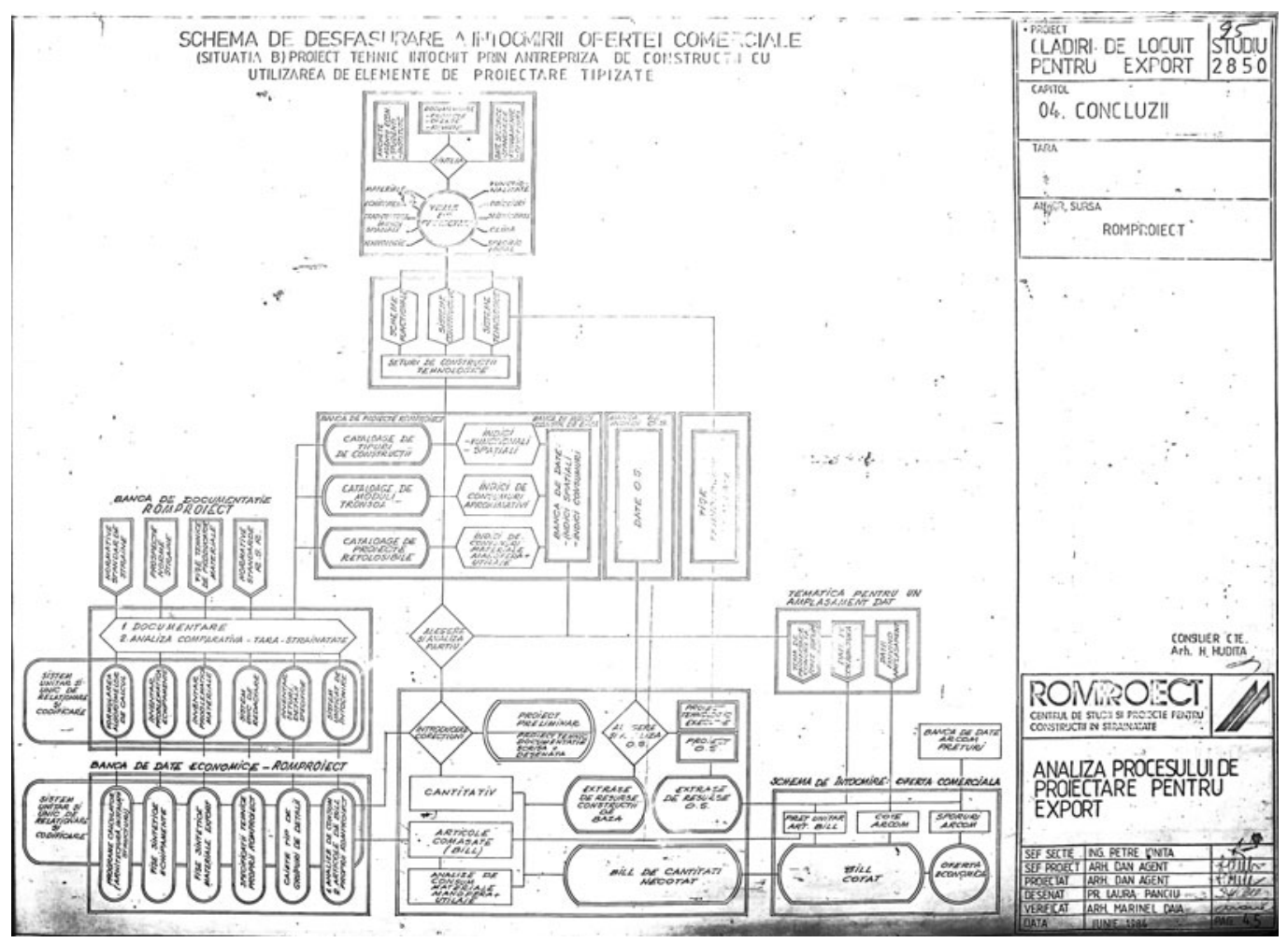

Figure 5. Diagram showing the development process of a design offer for export, 1984. Romproiect (Romania). Arhivele Naționale (Bucharest), f. Romproiect, 7099.

Barter transactions were widely used by Romanians in oil producing countries in the Middle East and North Africa, including Iraq, Libya and Algeria. In these countries, Arcom and other Romanian contractors, such as Romproiect (Centre for Studies and Design Abroad), constructed industrial plants, housing, as well as facilities for culture, sports, health and education. ${ }^{60}$ Some of these projects were designed by Romanians, but many were based on third-party designs. They were delivered by local institutions, often employing foreign architects, sometimes from socialist countries. ${ }^{61}$ Other buildings were planned by foreign consultants, either from the West or the East, including Bulgaria and Poland. ${ }^{62}$

In most cases, such third-party designs underwent a procedure called 'technological adaptation'. Romanian architects and engineers redrew blueprints and rewrote building specifications in such a way that they fit the capacities of Arcom and other Romanian companies involved [Figure 5]. So understood, technological adaptation was a translation procedure aimed at maximising competitive advantages that were made available to Romanian firms by the petrobarter agreements. Major among such advantages was the cheap labour of Romanian workers. ${ }^{63}$ To make use of that labour, buildings designed by third parties in large-scale prefabrication technology were often redrawn as structures cast on site, complemented by smaller prefabricated elements. In such projects, the Romanian workforce was not only employed on the construction sites but also in supporting facilities,

${ }^{60}$ Gheorghe Radu Stănculescu, 'A Brief History of Romproiect, 1981-2013', 2013, private archive of Gheorghe Radu Stănculescu, Bucharest (Romania); Vais, 'Exporting Hard Modernity’; Dossier 573, SARP archive, Warsaw (SARP).

61 Dossier 573, SARP.

62 Interview with Stănculescu; dossier 256, SARP.

63 AN, f. C. C. al P.C.R., s. Economică 1979-89, 60/ 1303. 
including quarries for aggregates, asphalt plants and workshops for the prefabrication of concrete, metal and wooden and ceramic elements. Such produced materials allowed to minimise non-Romanian purchases, and to save on import taxes for construction components. Materials which could not be produced on site were imported from Romania and other countries.

At times, the insistence on barter brought about losses, when entire shipments of wood joinery or tiles were damaged on their way from Romania and rejected by the client. ${ }^{64}$ In general, though, the procedure of technological adaptation proved effective and, for example, a 1981 report about Arcom's work in Libya registered that 58 per cent of materials came from Romania, which also included industrial products, such as lamps, cables, bathroom fixtures, ironware and pumps. Materials bought on the local market (32 per cent) were mostly aggregates for concrete, stone, fuel, lubricants, bitumen and masonry materials. The remaining 10 per cent was bought from third parties, such as West Germany, France and Italy, and included furniture, sanitation equipment and aluminium joinery, which were requested by the clients not satisfied with the quality of initially proposed Romanian products. ${ }^{65}$

This overview situates Arcom's work in Baghdad within the firm's longer efforts to adapt to the conditions of the competitive market in oil producing countries in the Middle East and North Africa and to the procedure of petrobarter specifically. ${ }^{66}$ While Arcom was paid for the construction of the abattoir buildings directly by the East Germans, its way of working was based on the procedure of technological adaptation as developed within petrobarter agreements. Architects from Arcom and other engineering institutes from Bucharest redesigned the execution plans for all buildings in reinforced concrete frame. They redrew large prefabricated elements foreseen by East German engineers so that the buildings could be cast on site by Romanian workers. ${ }^{67}$ Smaller concrete elements, such as railings and parapets, were prefabricated on site. ${ }^{68}$ In spite of these modifications, the new plans complied with East German specifications concerning thermal insulation, as well as plumbing and sanitation equipment. These specifications were the basis for the execution and the acceptance of materials and the final reception of the work. ${ }^{69}$ With the exception of cement and steel, for which Iraqis were in charge, other construction materials were brought from Romania. They were tested on the construction site and approved by Thier. ${ }^{70}$ The same procedures were applied to the design of the canteen for six hundred people, commissioned by the Iraqis directly from the Romanians and constructed by Arcom [Figure 6], and four villas for management on the Tigris river bank. ${ }^{71}$

Technological adaptation was supported by specific design tools implemented by Romanian companies in their commissions in Iraq and the region. Among these tools a central role was played by type designs, used to construct buildings on the basis of the same blueprint with few, if any, adaptations to individual sites. Typification was a precondition of industrialised construction in Romania and all other socialist countries. ${ }^{72}$ But the use of type designs was also advantageous for export contracts. Typification saved design labour and allowed clients to inspect earlier iterations of a particular building and to compare them with the clients' needs. Such designs facilitated economies of scale in the construction process, since a small range of typified components could be bought and shipped in bulk. Design institutes and contractors in socialist countries used type designs to compare the required

\footnotetext{
64 Ibid.

65 AN, f. C. C. al P.C.R., s. Economică 1979-89, 60/ 1303.

66 Interview with Niculae Besnea, Bucharest, May 2015; 'ID. 29 Million For Municipal Projects', Baghdad Observer (BO), 12 July 1974, 8; 'Modern Slaughter Houses and Meat Canning Factories', BO, 27 Sept. 1979, 2.

67 Miron Măsariu, 'Abator în Bagdad - Republica Irak', Arhitectura (Bucharest), 5 (1980), 26-7.

68 Interview with Besnea.

69 Măsariu, 'Abator'.

70 'Baghdad Modern Slaughterhouse - Gesamtablaufplan'.

71 Nicolae Besnea, 'Vile în Baghdad', Arhitectura (Bucharest), 6 (1984), 77.

72 Joachim Palutzki, Architektur in der DDR (Berlin: Reimer, 2000); Ana-Maria Zahariade, Arhitectura în proiectul comunist: România 1944-1989/ Architecture in the Communist Project: Romania 1944-1989 (București: Simetria, 2011).
} 


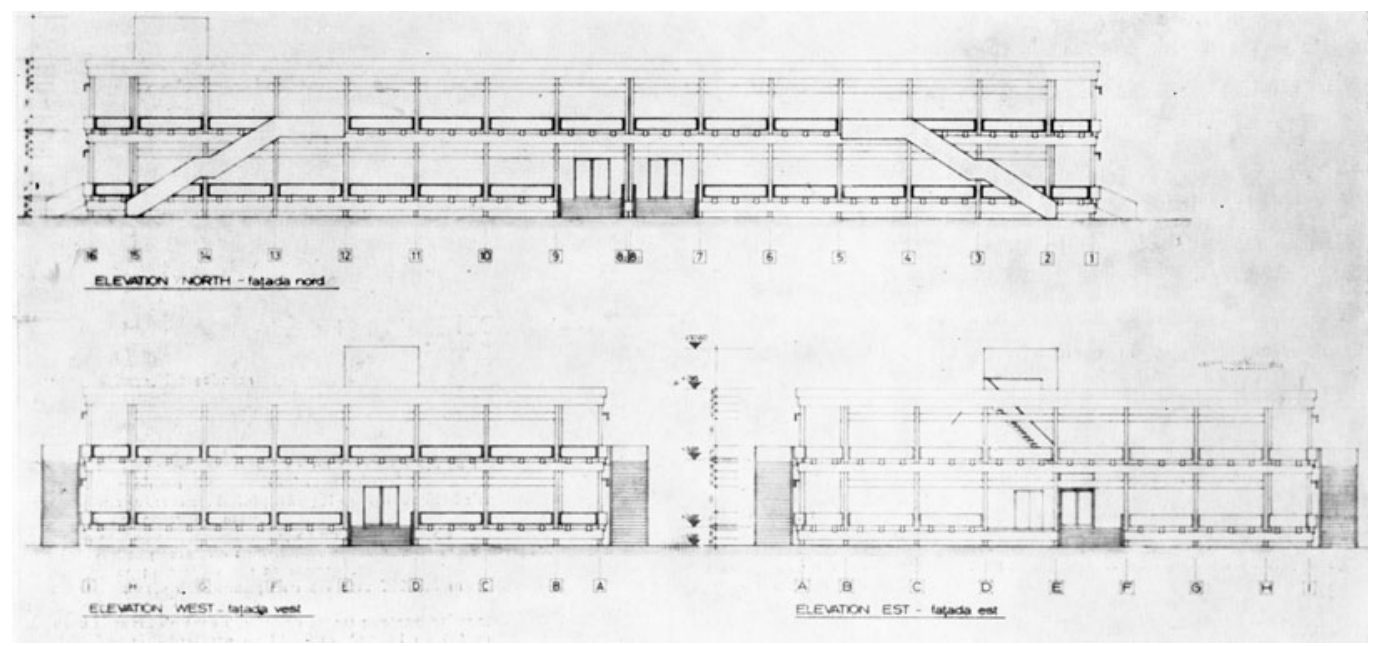

Figure 6. Design of the canteen on the Baghdad slaughterhouse compound, facades. 'Cantina abatorului din Baghdad', Arhitectura (Bucharest), 6 (1984), 80.

tasks with their capacities and to estimate costs and profitability of projects, as well as to coordinate, subdivide and manage the work of the institutions involved. ${ }^{73}$

Romanian and other Eastern European contractors produced catalogues of type designs, in particular housing, which were destined for Iraq and other countries in the Middle East and North Africa. Catalogues such as Housing Buildings for Export (Clădiri de locuit pentru export) issued by Romproiect (1984) show that Romanian contractors customised their offer to a much larger extent than, for example, East German design institutes. ${ }^{74}$ These catalogues used flowcharts to compose design solutions depending on the expected standards of finishing, systems of ventilation, heating and plumbing, as well as local building regulations and budgets of governmental commissioners. Such choices were then translated into construction systems and equipment supplied by the Romanian industry within intergovernmental barter agreements. These buildings were often delivered with fitted kitchens and bathrooms and sometimes fully furnished, including TV sets, stoves and sinks, with particular pieces of equipment selected by Iraqi clients in advance. ${ }^{75}$ Such comprehensive planning extended from individual buildings to whole neighbourhoods, and Romproiect's catalogues included also type plans of hotels, supermarkets, restaurants, kindergartens, schools and sports facilities [Figure 7]. ${ }^{76}$

The results can be seen in large housing projects in Iraq and elsewhere in the region, designed and, sometimes, constructed by Romanian companies during the two last decades of the Cold War [Figure 8]. These commissions exploited the advantages of petrobarter but they also testified to the fact that this 'exploitation' included the exploitation of Romania's own population. When interviewed today, several Romanian architects recall that they resisted going to the North African construction sites where they were often housed in camps far away from cities, with little else to do than work. The gearing of Romania's economy towards export since the early 1980s led to drastic cuts on imports and a severe austerity programme resulting in blackouts, freezing homes and workspaces and food

\footnotetext{
73 'Auftrag der Bauakademie der DDR - Muster- und Experimentalprojekt ... von 21.7.82', BA, DH2/ 4845.

74 Romproiect, 'Clădiri de locuit pentru export (II)', pr. no. 2850/1984, AN, f. Romproiect, 7099, 1.18; see also: AN, f. Romproiect, 7238, 7254, 7274, 7276, 7288; AN, f. C. C. al P.C.R., s. Economică 1979-89, p. 60/1981. For GDR projects in the region, see Stanek, Architecture, 214-22.

75 Arcom, Romproiect, 'Collective Dwelling GF2', n.d., AN, f. Romproiect, 7255; Romproiect, 'Clădiri de locuit pentru export (II)’, pr. no. 2850/1984, AN, f. Romproiect, 7099, 1.18; AN f. C. C. al P.C.R., s. Economică 1979-89, p. 60/1981.

76 'Romproiect', AN, f. Romproiect, 5709.
} 


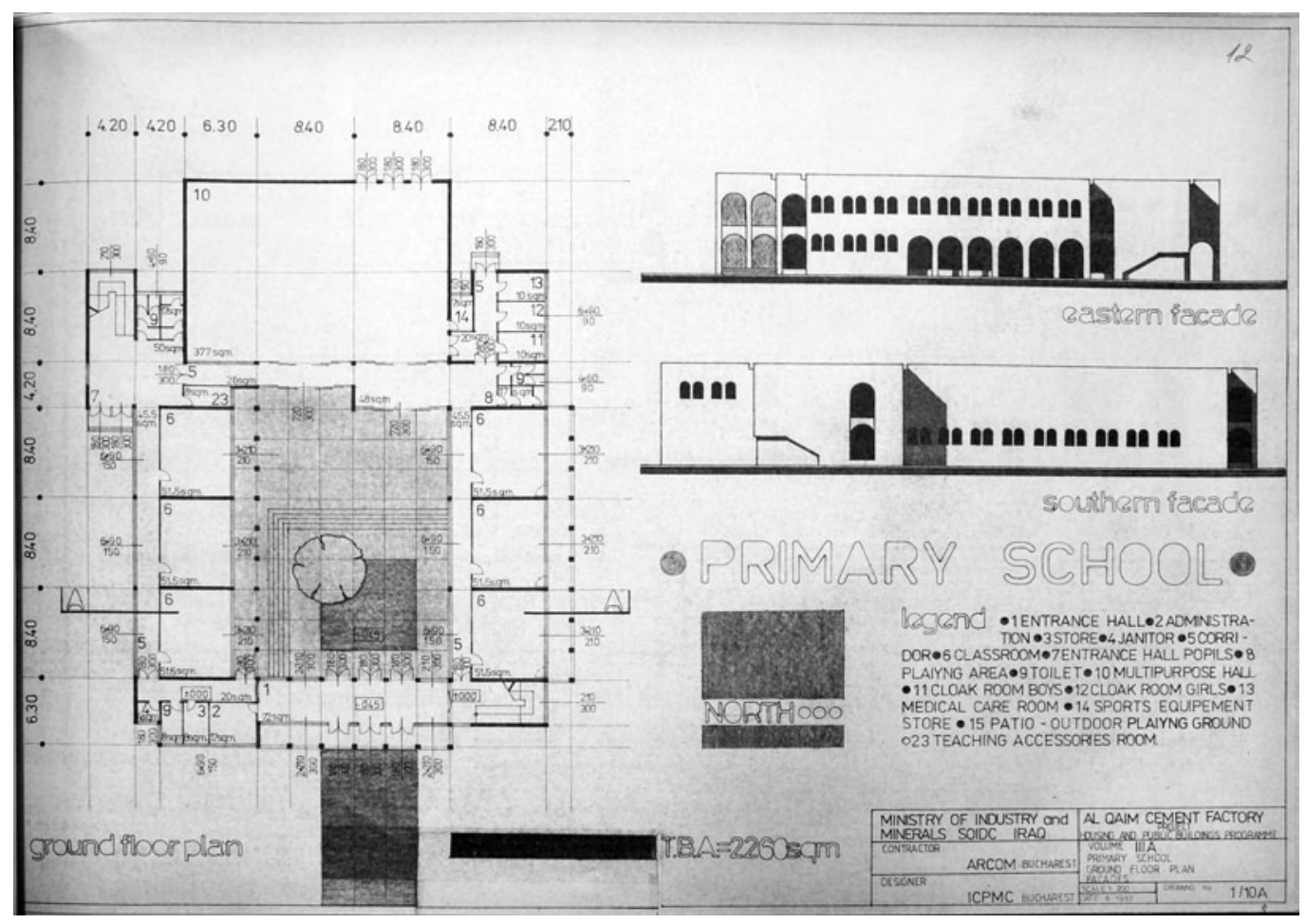

Figure 7. Primary school in al-Qaim, Iraq, 1982. Arcom, ICPMC (Romania). Arhivele Naționale (Bucharest), f. Romproiect, 7256.

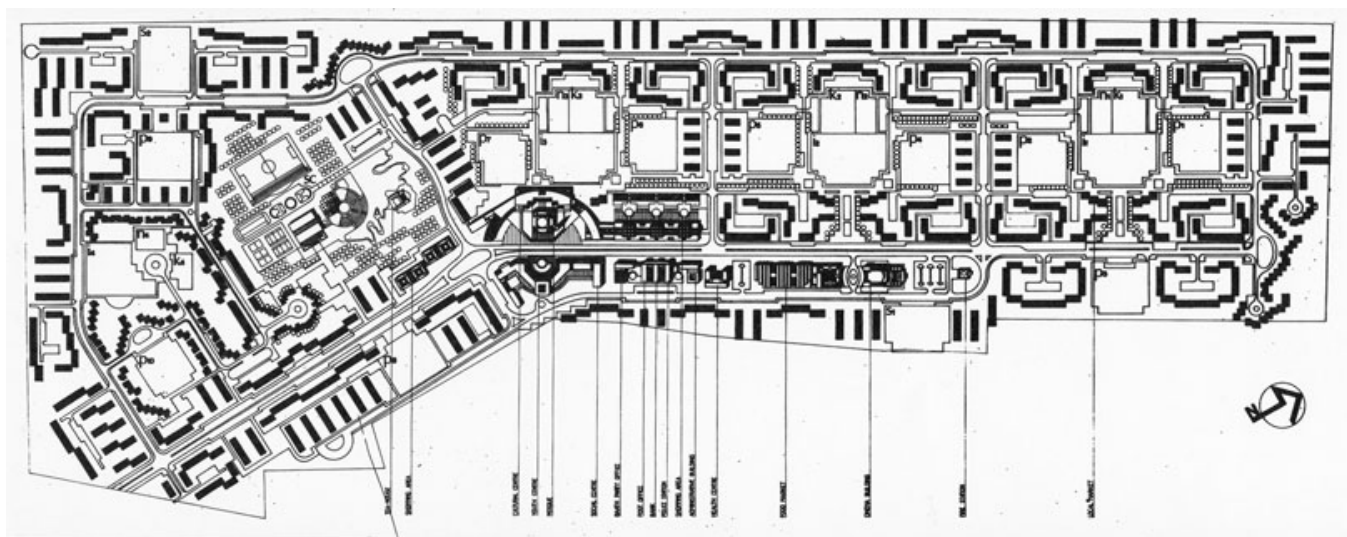

Figure 8. Master plan for a neighborhood in Mosul, Iraq, 3500 dwellings, 1983. Arcom, Romproiect (Romania). Arhivele Naționale (Bucharest), f. Romproiect, 7257.

rationing in Romania. ${ }^{77}$ These decisions, again, contrasted with those of East German politicians who resisted the diversion of resources from internal consumption. ${ }^{78}$

\footnotetext{
77 Kotkin, 'Kiss of Debt', 89.

78 Tanja Scheffler, 'Himmelskuppeln aus Jena: Die Architektin Gertrud Schille/ Celestial Domes from Jena: The Architect Gertrud Schille', in Christina Budde et al., eds., Frau Architekt: Seit mehr als 100 Jahren: Frauen im Architektenberuf/ Over 100 Years of Women as Professional Architects (Tübingen: Wasmuth, 2017), 300.
} 


\section{Conclusion: Liminal and Unequal Globalisation}

Against views of scholars who, in the wake of the Cold War, celebrated the end of a purported isolation of Eastern Europe from the globalisation processes, ${ }^{79}$ this article has shown that following the oil boom state socialist design institutes and building companies participated in the rapidly globalising market of design and construction services in Iraq. The position of Eastern European companies on this market was liminal and unequal, as they struggled with pressures from state and party leadership, currencies deemed less desirable, rigid corporate structures, and construction management procedures, systems of norms, standards and regulations considered by their clients to be inferior to the Western ones. This article has focused on the ways in which East German and Romanian managers, architects, engineers and decision makers responded to these conditions, tried to bypass the obstacles and looked for opportunities. In this way, it has clarified the terms of a globalisation characterised both by an accelerated interaction between actors across various political and economic systems, and by an uneven and unequal distribution of their roles.

The abattoir project showed that East German and Romanian enterprises worked in frameworks of similar political economies but also brought to the fore the division of labour between them and their different ways of operation. While East German companies struggled to implement organisational frameworks and procedures from East Germany, Romanian design institutes and contractors exploited the principle of petrobarter by 'technologically adapting' their work to the conditions on the ground. Such decisions, rarely visible from archives of political and economic institutions, came to the fore in design drawings and technical documentation of the Iraqi projects. By focusing on such sources, this paper showed how professionals on the ground translated the principle of petrobarter, and the political economy of foreign trade in socialist countries more generally, into design techniques, building programmes and construction methods. By following these processes, this study begins to clarify how the petrobarter procedure impacted urban landscapes in Iraq and elsewhere in the region, from industrial facilities such as the Baghdad abattoir, through infrastructure and social amenities, to housing neighbourhoods.

This article was largely based on East German and Romanian archives and used only few Iraqi sources, and hence the Iraqi counterparts of the Eastern Europeans remained in the background. But this background picture is a vivid one. Exchanges with socialist countries provided Iraqi authorities with resources implemented in programmes of state building, social development and economic modernisation. During periods of tensions with the West and economic crisis, Iraq received from Eastern Europe goods and services difficult to obtain in exchange for goods difficult to sell. In the wake of the oil embargo, authorities in Baghdad put pressure on Eastern European governments by combining political and economic threats and incentives. When dealing with their state socialist partners, Iraqi officials enforced their priorities by leveraging the anxieties of the East German leadership concerning West Germany and by exploiting the economic pressures under which Eastern European managers operated in Baghdad.

During the US-led invasion of Iraq in 2003, the south-eastern suburbs of Baghdad, where the abattoir was built, were the first to be bombed by the US military, which targeted the Iraqi command centre at Dora Farm. The war in Iraq, the others that followed in the region and the end of the Cold War disrupted the operations of Eastern European companies on the ground. However, some among them maintained their connections to the Middle East and North Africa. Their current work in the region testifies to the continuities of the patterns of division of labour which emerged in the course of the late 1970s and 1980s. The engagements of Eastern European companies are differentiated by scale, including their focus on mid-size commissions, with local actors hired for smaller jobs and Western firms for larger ones. These companies are often put in charge of earlier stages of construction work, while finishing and equipment are left for Western companies. The genealogy of these processes needs to be understood by accounting for the liminal and unequal character of Eastern Europeans' engagements

79 Elmar Altvater and Birgit Mahnkopf, Grenzen der Globalisierung: Ökonomie, Ökologie und Politik in der Weltgesellschaft (Munster: Westfälisches Dampfboot, 1999), 382. 
in the Middle Eastern construction markets since the 1970s. Such an account contributes to a conceptual shift towards a more antagonistic and heterogeneous understanding of globalisation processes during the final decades of the Cold War.

Supplementary material. The supplementary material for this article can be found at http://doi.org/10.1017/ S0960777321000333.

Acknowledgements. This article develops a chapter from my book Architecture in Global Socialism: Eastern Europe, West Africa, and the Middle East in the Cold War (Princeton, NJ: Princeton University Press, 2020). I would like to thank Miruna Stroe, Diane Barbé and Phuang Phan for assisting me in archival research in Bucharest and Berlin, and Ghada Al Slik, who advised me on the archival materials from Iraq. I am grateful to Sandrine Kott, Cyrus Schayegh and the two anonymous reviewers for their excellent comments.

Cite this article: Stanek $€$ (2021). Buildings for Dollars and Oil: East German and Romanian Construction Companies in Cold War Iraq. Contemporary European History 30, 544-561. https://doi.org/10.1017/S0960777321000333 